\title{
Vocabulary size of Turkish EFL learners at the tertiary level and its' impact on their reading and listening comprehension
}

\author{
Sedat Beceren ${ }^{1}$
}

\begin{abstract}
This study explores the relationship between vocabulary size of the Turkish EFL learners at the tertiary level and their reading and listening comprehension abilities. 60 randomly selected Turkish EFL learners enrolled in the ELT preparatory program participated in the study. The participants' vocabulary size, which was measured by Nation and Beglar's Vocabulary Size Test, found 5,785-word families in English. This result can be interpreted as meeting the standards of vocabulary size for undergraduate non-native students enrolled in an EMI university as they are required to have vocabulary knowledge of approximately 5000-6000-word families in English. The correlation and regression analysis processes revealed that there was a strong relationship between EFL learners' vocabulary size and reading skills and a moderate correlation was obtained between vocabulary size and listening comprehension. The results, which were in parallel with the previous research findings, were discussed regarding the importance of vocabulary in foreign language learning and some pedagogical suggestions were provided.
\end{abstract}

Keywords: Vocabulary Size, EFL Learner, Reading Comprehension, Listening Comprehension

Geliş Tarihi: 05.12.2019 - Kabul Tarihi: 07.05.2020 - Yayın Tarihi: 29.06.2020

DOI: $10.29329 /$ mjer.2020.258.11

\section{İngilizceyi Yabancı Dil Olarak Öğrenen Üniversite Seviyesindeki Türk Öğrencilerin Kelime Dağarcı̆̆ı ve Bu Bilginin Okuduğunu Anlama ve Dinlediğini Anlama Becerileri Üzerine Etkisi.}

Özet: Bu çalışmada İngilizceyi yabancı dil olarak öğrenen üniversite seviyesindeki Türk öğrencilerin kelime dağarcığı ile okuma ve dinleme becerileri arasındaki ilişki incelenmiştir. Rastgele seçilmiş 60 İngiliz Dili Eğitimi hazırlık programı öğrencisi çalışmaya katılmıştır. Katılımcıların kelime dağarcı̆̆ı Nation ve Beglar'ın kelime dağarcığı testi ile ölçülmüş ve İngilizce’ deki 5785 kelime ailesine hâkim olduklarını sonucuna ulaşılmıştır. Eğitim dili İngilizce olan üniversitelerde öğrenim gören ana dili İngilizce olmayan öğrencilerin yaklaşık 50006000 kelime ailesine hâkim olması gerektiğinden, bu sonuç Türk öğrencilerin bu standarttı karşıladığı şeklinde yorumlanabilir. Korelasyon ve regresyon analizleri İngilizceyi yabancı dil olarak öğrenen üniversite seviyesindeki Türk öğrencilerin kelime dağarcıkları ile okuma becerileri arasında kuvvetli bir ilişki olduğunu ancak dinleme becerileri ile 1 lımlı bir ilişki olduğunu ortaya koymuştur. Daha önce yapılan çalışmaların sonuçları ile benzerlik gösteren bu sonuçlar yabancı dil öğrenmede kelime bilgisinin önemi ile ilişkilendirilerek tartışılmış ve bazı eğitim öğretim önerileri sunulmuştur.

\footnotetext{
${ }^{1}$ Sedat Beceren, Assist. Prof. Dr., English Language Teaching Department, Çanakkale Onsekiz Mart University, ORCID: 0000-0002-4603-5079
}

Correspondence: sbeceren@comu.edu.tr 


\section{INTRODUCTION AND THEORETICAL FRAMEWORK}

Foreign language learning is considered as a multifaceted process involving various variables. In the history of foreign language learning and teaching, researchers have been investigating those variables to suggest better ways of language learning and teaching. Vocabulary, as being the main block of any language has been undervalued in any language learning and teaching research context and vocabulary learning and teaching has not been the core of research or the instruction in classroom even though it is defined as the central of language and a reliable indicator of language proficiency (Zimmerman, 1997; Richards \& Rodgers, 2001; Stæhr, 2008; Milton, 2013; Nation, 2013). Singleton (1999) illustrates the importance of words in a language by giving examples from daily expressions. According to him, the word in the expressions "I want a word with you, or I cannot understand a word he says (p. 8)" refer to the language itself and it is used as a synonym of language. Furthermore, Read (2000, p.1) defines words as "the basic building blocks of language, the units of meaning from which the larger structures such as sentences paragraphs and whole texts are formed". The early studies, which focused on the form of language, failed to explain the role of vocabulary for language proficiency. In the past, it was believed that grammatical structures were central to learning a foreign language. Vocabulary was only considered as a supporting component of language learning. In fact, one can communicate with poor accuracy or fluency level, but he cannot communicate without lexical knowledge. Krashen (1987) proposes a statement, which can be accepted as a proof of the importance of vocabulary. He states that students as travelers do not carry their grammar books but their dictionaries. Vocabulary is perceived as the first available resource that the learners depend on (Huckin \& Bloch, 1993) and rich vocabulary knowledge enables learners to perform the skills of listening, speaking, reading, and writing easily. Consequently, vocabulary knowledge is accepted as a key to language proficiency in both L1 and L2.

Grabe (2009) mentions that there is a booster in the number of empirical research studies, and books regarding the importance of vocabulary in language learning and teaching in the last 15 years. Even though the findings of the recent research regarding the vocabulary knowledge in a second/foreign language have revealed the significance of vocabulary in order to function in the language (Qian, 1999; Nation, 2001; Read, 2004; Tschirner, 2004; Zimmerman, 2005), there are still some issues which need to be investigated. One of them is the vocabulary size of the nonnative speakers of English studying at an EMI university in an EFL setting and the relationship of their vocabulary size and their receptive language skills. Therefore, this study attempts to investigate the vocabulary size of the Turkish EFL learners at the tertiary level and to seek for the relationship of vocabulary knowledge with their receptive language skills. 


\section{Vocabulary and reading studies}

The correlation studies mostly focus on the effect of vocabulary in reading. Reading is a complicated process, which requires learners to decode the printed material to comprehend the text. In this process, there are numerous variables such as metalinguistic awareness, L1 reading ability, L2 proficiency level and L1-L2 distance which affects the construction of mental representation of texts (Koda, 2005). Automaticity is necessary for fast and efficient word recognition and decoding and it can be improved by reading. Therefore, the relation between reading and vocabulary is bi-directional, since vocabulary generates reading comprehension and reading can make a great contribution to vocabulary growth (Nation, 2001; Koda, 2005).

In the correlation studies, it is aimed to find a close connection between reading comprehension scores and vocabulary size. Several vocabulary size tests and language proficiency measures such as TOEFL are used as a research tool in the studies conducting to investigate the relationship. Verhoeven (2000) reported that vocabulary size was the strongest predictor variable for reading comprehension. In another study with Droop, Verhoeven (2003) assessed the reading comprehension abilities of primary school language minority children in Netherland by comparing their vocabulary size and he concluded that there is a powerful casual effect relationship between reading and vocabulary. Furthermore, Nassaji (2003) asserted that the knowledge of vocabulary is the most essential component of L2 reading for tertiary level EFL students. Another study carried out by Qian (1999) with Chinese and Korean learners of English presented strong correlations coefficient between the reading section of TOEFL exam and Nation's Vocabulary Level Test Version A ( $r=0.78)$. In addition, Tschirner (2004) compared the relationship between L2 English vocabulary and reading proficiency regarding the demographic variables such as the length of stay in target country, English books read in a year, and learning strategies that the reader employs. Vocabulary size is stated as a reliable indicator both for reading comprehension and for other academic language skills. Moreover, Stæhr (2008) conducted a study investigating the relationship between vocabulary size and reading test scores of EFL learners studying at secondary education in Denmark. The results concluded that there is a direct connection between vocabulary knowledge and reading skill $(\mathrm{r}=0.83)$. In this research study, regression analysis scores are also provided to present the contribution of vocabulary knowledge to these test scores. According to the regression analysis results, vocabulary size can be attributed to $72 \%$ of variance for getting an average grade or above on the reading test. In another study, Milton, Wade, and Hopkins (2010) explored the impact of orthographic vocabulary size and phonological vocabulary size on IELTS test scores. The scores regarding the reading skill correlate well with orthographic vocabulary scores in which the words are given in written format $(r=0.70)$. Milton et al (2010) suggested that $48 \%$ of variance in reading test scores could be defined by differences in orthographic vocabulary size. As an overall conclusion, Staer (2008) indicated that research studies have revealed a 
remarkable correlation varying between 0.50 and 0.85 . Therefore, vocabulary size can be interpreted as the major factor in $\mathrm{L} 2$ reading success.

\section{Vocabulary and Listening Studies}

Improvement of listening skills for EFL learners is a bit problematic. EFL learners do not have much opportunity to have the frequent and qualified input in their real environment. They intend to use their native language outside of the formal education context. It is the natural process. In other words, the acquisition of this skill is only based on formal instruction in classrooms, and they may have limited exposure to English outside of the class. Therefore, EFL learners are usually faced with some difficulties in the acquisition of this skill such as limited vocabulary, lack of topical knowledge, diverse of accents, and fast speech rates, etc. The vocabulary size that they have can be considered as the most serious one among the other obstacles (Renandya \& Farrell, 2011) and it causes learners to avoid doing listening or to employ compensation strategies (Chang, 2005; Chang and Read, 2006).

In the literature of correlation studies, the topic of association between vocabulary size and listening ability has not been extensively explored when it is compared to the studies investigating the relationship between reading and vocabulary size. Kelly (1991 cited in Stæhr, 2008) proposed that the vocabulary knowledge is the major obstacle for EFL learning in listening process. However, her claim did not gain a seat due to lack of empirical evidence. In the following years, Beglar and Hunt (1999) conducted a study in which they compared TOEFL listening scores of 496 Japanese high school students with four versions of the 2,000-word level of the Vocabulary Level Test. They also correlated the listening scores of 464 Japanese high school students with four versions of the University Word List. Their study concluded that the correlation between TOEFL listening scores were similar for both vocabulary measures $(r=0.45$ and $r=0.45)$. However, the results for listening comprehension were lower than the findings of reading and writing which were also investigated in the same study. Stæhr (2007) revealed a more considerable correlation in a study in which he compared 115 advanced EFL learners' receptive vocabulary size and their listening comprehension ability $(r=0.70)$. In his study, he employed Nation's Vocabulary Level Test and Cambridge Certificate of Proficiency in English as test measures. Stæhr (2008) conducted another study similar to the previous one. In this study, he investigated the relationship between vocabulary size and listening scores of 88 EFL learners. The research results revealed a considerable relation $(r=0.69)$. Milton et al (2010) carried out a study with 30 EFL learners in which they assessed the contribution of two different vocabulary knowledge, namely orthographic vocabulary size (X_Lex) and phonological vocabulary size (Aural Lex) to IELTS test scores on each level. The vocabulary scores of learners in both tests correlated with listening comprehension scores with a coefficient score of 0.48 (Xlex) and 0.67 (Alex). Linear regression analysis revealed that $51 \%$ of variance in listening scores could be associated with both vocabulary test scores. 


\section{Vocabulary Size}

Research on the correlation of vocabulary size and reading and listening comprehension have shown that there is a strong statistical correlation among the parties. In other words, comprehensive vocabulary knowledge enables better comprehension. However, a question arises here regarding the size of vocabulary for adequate comprehension of reading and listening texts. It is the question of "how many words should an EFL learner need to know in order to perform reading and listening comprehensively?". In this study, vocabulary knowledge refers to the receptive vocabulary as it aims to test reading and listening. In the early vocabulary size studies, 3000 words are believed to provide 95\% of text coverage. Laufer (1992) states that one should have a 95\% lexical coverage to comprehend a text adequately. Hu and Nation (2000) go a bit further and they claim that learners need to know $98 \%$ of the words in a given text for fluent reading. The recent research by Laufer (2010) revises the lexical threshold level for reading comprehension. In her study, she suggests two threshold levels for adequate $\mathrm{L} 2$ reading comprehension. The first one is introduced as optimal level referring to the knowledge of 8,000-word families which ensures $98 \%$ of the coverage. The other is presented as the minimal level covering 4,000-5,000-word families which results in the coverage of $95 \%$. On the other hand, Nation and Beglar (2007) argue that one should almost have a vocabulary knowledge referring to $8,000-9,000$-word families tin order to perform some daily tasks such as reading a book, or magazines, watching films, and listening to a sociable conversation. In other words, $98 \%$ of coverage enables learners to read fluently without instructional aide.

Regarding the threshold level for understanding the spoken discourse, Nation (2006) proposes that a vocabulary size of 6,000-7,000-word families is required to reach text coverage of $98 \%$. Nation and Beglar (2007) provide a table for the required vocabulary size in order to perform different receptive tasks (table 1). The outcome of his research is emerged from the analysis of Wellington Corpus of Spoken English

Table 1. Vocabulary sizes needed to get $98 \%$ coverage (including proper nouns) of various kinds of texts

\begin{tabular}{|l|c|c|}
\hline Texts & $98 \%$ coverage & Proper Nouns \\
\hline Novels & 9,000 -word families & $1-2 \%$ \\
\hline Newspapers & 8,000 -word families & $5-6 \%$ \\
\hline Children's movies & 6,000 -word families & $1.5 \%$ \\
\hline Spoken English & 7,000 -word families & $1.3 \%$ \\
\hline
\end{tabular}

(Nation \& Beglar, 2007, p.7)

\section{The Present Study}

In the context of Turkey, students have been studying English as a foreign language for almost 11 years before attending to the university and there is no information related with their vocabulary size stated in any official document of Ministry of National Education (MoNE). The students who want to study at the English Language Teaching Departments at the universities in Turkey have to take 
a university entrance exam in English, mainly focused on receptive skills. Furthermore, most of the universities required these students to have an exemption exam in order not to study a preparatory class. Their vocabulary size has a crucial factor in their success in each of these exams and for their future academic career. Therefore, the present study aims to investigate the vocabulary size of Turkish EFL students studying at the ELT preparatory program as there is scarcely research focusing on this subject matter. The study further aims to correlate the students' receptive vocabulary size with their reading and listening test scores in which learners mostly depend on their receptive vocabulary size. Their vocabulary size is discussed in the lights of the aforementioned research findings whether they reach the threshold level to study in an English medium university department.

The following research questions were addressed in this study:

1) What is the vocabulary size of Turkish EFL learners studying at the ELT preparatory program at a state university located in the southwest of Turkey?

2) To what extent can vocabulary size be associated with the listening comprehension skill and the reading comprehension skill?

\section{METHODOLOGY}

\section{Participants and settings}

The participants of the present study consisted of a total number of 60 randomly selected students enrolled in ELT preparatory program at a state university in Turkey. The participants' ages were ranging 17 to 23 , they graduated from three different high schools, namely General High Schools, Anatolian High Schools, and Anatolian Teacher Training High schools and majority of participants $(51,7 \%)$ graduated from General High Schools. 11 of the participants (18.3\%) declared that they had prep in their high school or at another university. They had been taught English for 11 years as a part of National curriculum and they had extensive English courses in their last two years both in their schools and in private courses, which prepared students for university entrance exam. MoNE (2016) asserts that the high school which offers preparatory class aim to reach B2+/C1 Level at the end of four-year English instruction. Therefore, participants are assumed to have English Knowledge at least B2+ according to the CEFR level bands.

\section{Data Collection Instruments}

In this study, quantitative analysis was employed to assess the gathered data. A vocabulary size test, and the reading and listening section of a retired TOEFL (October 2003 version) were employed as data collection instruments.

There are various existing vocabulary size tests assessing the receptive vocabulary size of participants such as The Vocabulary Levels Test, The Academic Word List, The Eurocentres Vocabulary Size Test 10ka, X_Lex, the Swansea Levels Test, and the Aural Lex. These test measures 
are widely used in the related literature. However, the Vocabulary Size Test (Nation \& Beglar, 2007) which is the most recent test measure in the literature was selected. The Vocabulary Size Test was developed by Nation and Beglar in 2007 for measuring non-native speakers' vocabulary size from the $1^{\text {st }} 1000$ to the $14^{\text {th }} 1,000$-word families in English (available on https://www.lextutor.ca/tests/vst/). The authors indicate some rationales for the necessity of measuring a non-natives vocabulary size. The first one is to determine the vocabulary size of the EFL learners at university level in order to perform such receptive tasks as reading a newspaper, reading a novel, listening to a friendly conversation and watching a movie. The second one is to tabulate the growth of learners' vocabularies and the third rationale is to compare the vocabulary size of non-natives with native speakers.

The vocabularies used in test based on the British National Spoken Corpus. The order of the words is related with the frequency of their occurrence. There are 140 items in the test, which represent the most frequent 14,000-word families in English. Ten words are chosen from each 1,000word level. It is in the multiple-choice format, however; learners should have an idea about the meaning of the word to answer the questions because distracters are also provided for each test item. Therefore, it is a bit more demanding than the other test measures.

The evaluation of the test is simple and easy. Since there are 140 items representing 14000-word families in English, test takers score is designated by their correct answers. If a learner answers all the items correctly, it can be assumed that he/she has the knowledge of the most frequent 14000-word families in English. However, it does not guarantee that the test taker can utilize this vocabulary knowledge in the skills requiring production.

Nation \& Beglar, (2007) states that the use of this test gives comprehensible information about the L2 vocabulary size required to study at the tertiary level. The studies with the test affirm that the undergraduate non-native students enrolled in an EMI university are required to have vocabulary knowledge of approximately 5000-6000-word families in English. As for the competent non-native $\mathrm{PhD}$ students, around 9000-word knowledge seems appropriate. Therefore, this test measure is more appropriate to the present study environment.

The validity of the test was conducted by Beglar (2009). The test was administered to 19 native speakers of English and 178 native speakers of Japanese and it was validated by employing the Rasch model. Beglar (2009) suggests that researchers and teachers are benefited from the new receptive vocabulary size test.

A retired TOEFL (October 2003 version) test was employed to measure the participants' reading and listening comprehension. It is a paper based TOEFL registered in 2003. The reading section includes five passages aiming to measure the ability to understand non-technical reading material and each passage is followed by 9 or 11 questions. There were 50 multiple-choice questions in the test and participants were allowed 75 minutes to complete the test. Therefore, the correct 
answers of the participants were multiplied by two to set their final score. The listening section of the TOEFL test includes three distinct parts, which aims to assess the ability of comprehending spoken English. In the first part, test-takers hear short conversations between two people. In the second one, they hear longer conversation and they hear several talks in the final part. After each conversation or talk, they are asked a question related with the listening text. There are again 50 multiple-choice questions in those three parts. The participants listened the three parts twice and 40 minutes were allocated for participants to complete the test. Therefore, the same procedure with reading was followed for calculation of participants' final scores.

\section{PROCEDURES}

\section{Method of Data Collection}

The data was gathered towards the end of the academic year. The randomly selected students were explained the study purposes as an awareness raising activity. It was aimed to raise the students' awareness for the data collection process due to the number of questions in vocabulary size test and TOEFL exam. The participants were also ensured confidentiality and anonymity. The test measures were administered to the participants in one-week intervals to prevent the data loss and not to overwhelm the participants. In this process, participants were encouraged to read the items and questions carefully before giving their final decision. To increase the credibility of the responses, participants were requested to ask anything that they did not understand.

\section{Method of Data Analysis}

To analyze the data collected in connection with the aim of the study, some statistical techniques such as frequency, percentage, mean, and Pearson correlation and Regression analysis were employed.

\section{RESULTS}

Research question 1: "What is the vocabulary size of Turkish EFL learners studying at the ELT preparatory program at a state university located in the southwest of Turkey?"

The purpose of the first research one is to define the vocabulary size of the Turkish EFL learners studying at the tertiary level in Turkey, which has been an unsought research area. The vocabulary size of the participants obtained by means of Nation and Beglar's Vocabulary Size Test are presented in table 2 below.

Table 2. Means, standard deviations (SD) and score ranges of Vocabulary Size Test

\begin{tabular}{|l|l|l|l|l|l|l|}
\hline & $N$ & Min & Max & Mps & Mean & Sd. \\
\hline Vocabulary Size & 60 & 4200 & 8200 & 14000 & 5785 & 8.71 \\
\hline
\end{tabular}

Note: Mps= Maximum possible score 
The descriptive statistics revealed that the mean of Turkish EFL learners' vocabulary size was average ( $\overline{\mathbf{X}}=5785$ ). According to Nation and Beglar (2007), the non-native students studying at an English medium university at the undergraduate level have a vocabulary size around $5000-6000$. The results are parallel with their assumptions. This can be interpreted as the vocabulary knowledge of 5,785-word families in English, which is quite sufficient to follow courses in English. The interesting result in this table is the maximum score of 8,200 . When the frequency statistics were analyzed, it was observed that eight of the students had the knowledge of word families around 6,900 and above. It is a bit surprising that why these students are studying at the preparatory class. The document analysis of the exemption results revealed that five of these students did not take the exemption exam.

Research question 2: "To what extent can vocabulary size be associated with the listening comprehension skill and the reading comprehension skill?"

The purpose of the second research question was to explore the relationship between vocabulary size and the comprehension of listening and reading. Therefore, participants' scores on reading comprehension and listening comprehension test were analyzed. The descriptive statistics of the reading and listening test are provided in table 3.

Table 3. Means, standard deviations (SD) and score ranges of Vocabulary Size Test

\begin{tabular}{|l|l|l|l|l|l|l|}
\hline & $N$ & Min & Max & Mps & Mean & Sd. \\
\hline Reading Score & 60 & 40 & 72 & 100 & 53.98 & 7.38 \\
\hline Listening Score & 60 & 26 & 76 & 100 & 45.90 & 9,70 \\
\hline
\end{tabular}

Note: Mps= Maximum possible score

As it is demonstrated in table 3 , participants scored better in reading comprehension test $(\overline{\mathbf{X}}=$ 53.98) than they did in the listening comprehension test ( $\bar{X}=45.90)$. Participants' scores are ranging from 40 to 72 in the reading text. However, the range of scores in the listening test is a bit farther than the reading scores. This can be explained by the students' prior exposure to the reading texts. In the Turkish EFL context, learners are exposed to reading materials and testing in this subject more often than the listening materials and testing in this field.

Then, Pearson Correlation analysis and Regression analysis were conducted to examine the correlation between the vocabulary size of the EFL learners and their comprehension scores in reading and listening skills. The results of analysis are presented in Table 4.

Table 4. Pearson correlation between the scores of vocabulary size test and reading and listening comprehension tests $(n=60)$

\begin{tabular}{|l|l|l|}
\hline & Reading & Listening \\
\hline Vocabulary size & $.74^{* *}$ & $.49^{* *}$ \\
\hline
\end{tabular}

Correlation is significant at the 0.01 level (2-tailed)

The two-tailed Pearson Product Moment revealed a strong correlation between vocabulary size and reading comprehension $(\mathrm{r}=0.74, \mathrm{p}<.001)$. The finding of the correlation is similar with the 
previous studies mentioned in the literature and it again confirms that vocabulary can be one of the main indicators of success in reading. The vocabulary size was correlated moderately with listening comprehension scores $(r=0.49, \mathrm{p}<.001)$ in the present study which is comparable to Beglar and Hunt's (1999) study in which they employed TOEFL listening test as a measure and found moderate correlation. The study confirms that reading is more associated with vocabulary size. Furthermore, a linear regression analysis was carried out to determine the contribution of vocabulary size to the participants' results in both reading and listening tests. The value of $\mathrm{R}^{2}$ in the regression analysis results, which is a measure of how much of the variability in the outcome is accounted for by the predictor variable, verifies that vocabulary size accounts for $54 \%$ of the variance in the reading comprehension scores $\left(\mathrm{R}^{2}=0.540\right)$. On the other hand, only $23.6 \%$ of the variance in the ability to attain a better score in the listening test can be justified by vocabulary size. This means that there are other contributing factors to listening success rather than the vocabulary size $\left(\mathrm{R}^{2}=0.236\right)$. Although it can be considered as a weak or low support, the vocabulary size is still a considerable factor in listening comprehension.

\section{DISCUSSION AND CONCLUSIONS}

The examination of Turkish EFL learners' receptive vocabulary size at the university level indicates that preparatory program students have a vocabulary size of 5000-6000-word families in English. This can be a comprehensible answer to the Nation's (2006, p.1) question of "how large a vocabulary is needed for reading and listening?" In his article, Nation argues that an 8,000 to 9,000 word-family vocabulary size is required to fully understand a written text and a 6,000 to 7,000 vocabulary size for spoken text without an instructional aide. Furthermore, he claims that non-native speakers of English at the tertiary level should have at least an amount of 5,000 to 6000-word family knowledge to handle the requirements of the higher education. According to the Brown Corpus, an amount of 5,000-vocabulary size enables learners to understand the $88.7 \%$ of the written texts. Therefore, the vocabulary size of the Turkish EFL learners can be considered as satisfactory if we keep in mind that these learners are at the preparatory program and they have four more year of formal education. Nation and Beglar (2007) designate the vocabulary size target as 8,000-word families for learners who want to handle authentic written and oral texts. It is a pleasure to know that Turkish EFL learners are not far away from this critical target. The most important way of getting to this target for learners is the improvement of their vocabulary size. As it accepted throughout the language-teaching field, vocabulary is central to language learning.

The correlation findings of the present study highlight the critical importance of vocabulary for language skills especially for reading proficiency. Reading accepted both as a receptive and productive skill was detected as the most associated skill with receptive vocabulary that is an expected result due to the previous researches findings. Reading established a high statistical correlation with vocabulary size displaying a coefficient of 0.74 . Based on the regression analysis result the variance of the success 
in reading performance could be clarified by vocabulary size with a percentage of 54 . As it is mentioned in the previous paragraph, the vocabulary size is an inevitable input in solving the mystery of a reading text. EFL learners' success in reading ability is enhanced by the improvement of their vocabulary size.

Furthermore, the findings of the present study revealed that listening comprehension is also fostered by the vocabulary size, which are in parallel with the preceding research results. However, the contribution of vocabulary to the listening comprehension is not as clear as it is in the skill of reading. The study revealed a modest correlation between the parties by producing a 0.49 coefficient. Some reasonable explanations are offered to the situation in the literature. The most revealing explanation is related with the test measures (Stæhr, 2008). Most of the vocabulary assessment tools just focus on orthographic knowledge of the word. In the present study, the vocabulary size test is also one those assessment tools which measures the knowledge of the written form of the word. However, the listening skill requires the ability to recognize the phonological form of the words. In a recent study, Milton et al (2010) employed two different test measures namely X_Lex focusing on orthographic vocabulary size and A_lex aiming to measure phonological vocabulary size in assessing the learners' vocabulary size. The study reveals that the correlation between the reading scores and $\mathrm{X} \_l$ lex is much higher that the correlation with A_Lex scores whereas the listening scores are associated with the A_Lex score in a more coefficient than the $X \_l$ lex scores. Therefore, the use of multiple test measures is necessary for investigating the relationship between vocabulary size and language proficiency. Another possible explanation is the requirement of processing skills in listening. The working memory can be overloaded in decoding the phonological input and fails to access the lexicon. In addition to this, another potential factor for the weak correlation is due to the lack of listening practice for Turkish EFL learners. In Turkish state schools, much attention to listening practice is not paid and learners cannot reach the automatization in this skill.

On the other hand, 23, $6 \%$ of the variance in the listening scores can be explained by the effect of vocabulary size. The correlation between listening scores and vocabulary size is still a considerable ratio $(r=0.49, p<.001)$. It can be interpreted that listening skill is less dependent to vocabulary when it is compared with the reading skill, but vocabulary size can still be considered as a reasonable factor in listening proficiency.

The findings of the presents study identify a number of pedagogical implications for Turkish EFL context. Since Turkey is a still growing country, and an EU member candidate, it is necessary to foster the foreign language teaching situation to catch the modernity and to carry our nation to its deserved place in the science world. Given that the vocabulary is the main gate of language proficiency in skills, the vocabulary instruction should be emphasized in language classroom. As Nation $(2006,2007)$ proposes the goal of knowing 8,000 word families is crucial for non-native speakers to perform the language without instruction, a target of vocabulary size should be designated 
for each level namely for primary schools, secondary schools and preparatory programs at the university level in Turkey. Curriculum plans, assessments measures, and educational policies should be redesigned by considering the amount of vocabulary that is to be reached. Learning goals and objectives should include the targeted vocabulary size particularly for Turkish context. The explicit vocabulary instruction sections can be added to the English syllabi of the programs providing L2 instruction. Schmitt (2008) suggests that both explicit and implicit vocabulary learning activities should be integrated to the language curricula or syllabi and language teachers should be encouraged in implementing these activities. Intensive and extensive reading materials can be assigned to EFL learners to increase the exposure rate of vocabulary in terms of reading instruction. Listening activities that is supported with the listening scripts can be employed in language classrooms to enhance the automaticity of word recognition through activating both channels.

Another suggestion can be addressed to the business sector, namely teaching material publishers. They are recommended to pay more attention in preparing course books including individual word power sections or provide fascinating ways to facilitate novel words to L2 learners.

Although the present study reveals that Turkish EFL learners studying at tertiary level have almost satisfactory vocabulary size, future quantitative vocabulary studies are needed for comparison and evaluation of EFL learners' vocabulary size. These studies will provide rationales for EFL teachers and course material developers to review their methodologies and materials.

A final suggestion can contribute the future EFL generations. The vocabulary size of ELT students required before their graduation can be determined in advance and the programs provide language courses for enriching the vocabulary size of prospective language teachers. Future teachers who are aware of the importance of vocabulary in language learning may pay more attention to vocabulary instruction in their future career.

The present study employed a testing measure focusing of the frequency of words, however; there are other dimensions of vocabulary such as depth. Therefore, future research is needed for other scopes of vocabulary size in relation with language proficiency.

\section{REFERENCES}

Beglar, D. (2009). A Rasch-based validation of the Vocabulary Size Test. Language Testing, 27, 101-118. https://doi.org/10.1177/0265532209340194

Beglar, D., \& Hunt, A. (1999). Revising and validating the 2000 word level and the university word level vocabulary tests. Language Testing, 16 (2), 131-162.

Chang, C. S., (2005). The effect of lexical support in EFL listening comprehension tests. The Proceedings of the 22nd International Conference on English Teaching and Learning in the Republic of China. Crane, Taipei, Taiwan,13-27.

Chang, C. S., \& Read, J., (2006). The effects of listening support on the listening performance of EFL learners. TESOL Quarterly 40, 375-397. 
Droop, M., \& Verhoeven, L. (2003). Language proficiency and reading ability in first- and secondlanguage learners. Reading Research Quarterly, 38 (1), 78-103.

Grabe, W. (2009). Reading in a second language. Cambridge, UK: Cambridge University Press.

Hu, M., \& Nation, I. S. P. (2000). Unknown vocabulary density and reading comprehension. Reading in a Foreign Language, 13, 403-430.

Huckin, T., \& Bloch, J. (1993). Strategies for inferring word meaning in context: A cognitive model. In T. Huckin, M. Haynes, \& J. Coady (Eds.), Second language reading and vocabulary acquisition (pp. 153-178). Norwood, NJ: Ablex.

Koda, K. (2005). Insights into second language reading: A crosslinguistic approach. Cambridge: Cambridge University Press.

Krashen, S. D. (1987). Principles and practice in second language acquisition. London: Prentice Hall International.

Laufer, B. (1992). How much lexis is necessary for reading comprehension? In H. Bejoint \& P. Arnaud (Eds.), Vocabulary and applied linguistics (pp.126-132). Basingstoke \& London:Macmillan.

Laufer, B. (2010) Lexical threshold revisited: Lexical text coverage, learners' vocabulary size and reading comprehension, Reading in a Foreign Language, 22, (1), 15-30

Meara, P., \& Milton, J. (2003). X_Lex, the Swansea Levels Test. Newbury: Express.

Milton, J., Wade, J., \& Hopkins, N. (2010). Aural word recognition and oral competence in a foreign language. In R. Chacón-Beltrán, C. Abello-Contesse, M. Torreblanca-López, \& M. D. LópezJiménez (Eds.), Further insights into non-native vocabulary teaching and learning (pp. 83-97). Bristol: Multilingual Matters.

Milton, J. (2013). Measuring the contribution of vocabulary knowledge to proficiency in the four skills. In C. Bardel, C. Lindqvist \& B. Laufer (Eds.), L2 vocabulary acquisition, knowledge and use. New perspectives on assessment and corpus analysis. Eurosla Monographs Series, 2. EUROSLA.

MoNE, (2016). Preparatory Class, 9th-12th Grades English Curriculum. Ankara: MEB http://mufredat.meb.gov.tr/ProgramDetay.aspx?PID=783

Nassaji, H. (2003). L2 vocabulary learning from context: Strategies, knowledge sources, and their relationship with success in L2 lexical inferencing. TESOL Quarterly 37, (4), 645-70.

Nation, I. S. P. (2001). Learning vocabulary in another language. Cambridge: Cambridge University Press.

Nation, I. S. P. (2006). How large a vocabulary is needed for reading and listening? The Canadian Modern Language Review, 63, 59-82.

Nation, I.S.P. \& Beglar, D. (2007). A vocabulary size test. The Language Teacher 31, (7), 9-13.

Nation, I. S. P. (2013). Learning vocabulary in another language. Cambridge: Cambridge University Press. https://doi.org/10.1017/CBO9781139858656

Qian, D. D. (1999). Assessing the roles of depth and breadth of vocabulary knowledge in reading comprehension. The Canadian Modern Language Review, 56, 282-308

Read, J. (2000). Assessing vocabulary. Cambridge: Cambridge University Press.

Read, J. (2004). Research in teaching vocabulary. Annual Review of Applied Linguistics, 24, 146-161. 
Renandya, W. A., \& Farrell, T. S. C. (2011). Teacher, the tape is too fast! Extensive listening in ELT. ELT Journal, 65(1), 52-59.

Richards, J. C., \& Rodgers, T. S. (2001). Approaches and methods in language teaching (2nd ed.). Cambridge: Cambridge University Press.

Schmitt, N. 2008. Instructed second language vocabulary learning. Language Teaching Research 12, (3), $329-63$.

Singleton, D. (1999). Exploring the second language mental lexicon. Cambridge: Cambridge University Press.

Stæhr, L. S. (2007). The relationship between vocabulary knowledge and listening comprehension in English as a foreign language. Copenhagen Business School

Stæhr, L. S. (2008). Vocabulary size and the skills of listening, reading and writing. Language Learning Journal, 36, 139-152.

Tschirner, E. (2004). Breadth of vocabulary and advanced English study: An empirical investigation. Electronic Journal of Foreign Language Teaching, 1, (1), 27-39.

Verhoeven, L. (2000). Components in early second language reading and spelling. Scientific Studies of Reading, 4, 313-330.

Zimmerman, C. B. (1997). Historical trends in second language vocabulary instruction. In J. Coady \& T. Huckin (Eds.), Second language vocabulary acquisition: A rationale for pedagogy (pp. 5-19). Cambridge: Cambridge University Press.

Zimmerman, K. (2005). Newly placed versus continuing students: comparing vocabulary size. TESL Reporter, 38, (1), 52 - 60. 